\title{
Developing A Conceptual Framework of Product-Service System Management Toward Firms' Sustainability for Indonesian Industrial Estate Firms
}

\author{
Christina Wirawan ${ }^{*}, 1,2$, Gatot Yudoko ${ }^{1}$, Yuliani Dwi Lestari ${ }^{1}$ \\ ${ }^{1}$ School of Business Department, Institut Teknologi Bandung, Bandung 40123, Indonesia \\ ${ }^{2}$ Industrial Engineering Department, Universitas Kristen Maranatha, Bandung 40164, Indonesia
}

\begin{tabular}{l} 
A R T I C L E I N F O \\
\hline Article history: \\
Received: 15 August, 2018 \\
Accepted: 14 September, 2018 \\
Online: 25 September, 2018 \\
\hline Keywords: \\
Product Service System \\
Sustainability \\
Firm's Life Cycle \\
Indonesian industrial estate firms
\end{tabular}

\section{Introduction}

This article is an extension of our previous work published at 2017 IEEE International Conference on Industrial Engineering and Engineering Management (IEEM) [1]. Our previous work discussed about types of PSS and business activities implementation in Indonesian industrial estate firms in order to help them sustain [1]. Industrial estates firstly initiated in Europe, such as England; Netherland; Germany; and the United States of America in the late 1800s [2]. They are built as a center and localization for industrial companies [2]. Following after, many countries also built industrial estates for several reasons such as environmental and economic growth [3]. Industrial estate firms have obligation to provide land; building; infrastructures; utility

${ }^{*}$ Christina Wirawan, Ganesha 10, Bandung, Indonesia, +62 8122119907

Email: christina.wirawan@sbm-itb.ac.id

\begin{abstract}
A B S T R A C T
Industrial estate firms have important roles in national development through the industrial development. In the course of their life, industrial estate firms ought to follow the firm life pattern. The common pattern shows that the period, in which the firm experiences strategy realization are not precisely implemented during each stage, especially decreases period, it will be difficult for the firm to survive.

A strategy that can be implemented by industrial estate firms in order to be sustained is to manage Product-Service System (PSS). It is a well-known concept in creating opportunities a new business model in which firms can offer bundles of products and services to their instead of merely tangible products. PSS can be distinguished into three types of the firm life cycle in accordance with its condition to maintain the company's sustainability at every stage of its life cycle. In this article, we construct a conceptual framework to help inesian industrial estate firm to be alert on the need to focuses on providing services tead of only selling products. This article also shows that different PSS management would be needed in particular stages of firm life cycle. Applying suitable PSS and business activities based on PSS in each stage of the firm life cycle can lead to gaining a competitive PSS concept concerning each stage of firm life cycle at industrial estate firms.
. The
\end{abstract}

services [4]; and amenities [5] for industrial companies in the estate and community. Industrial estates, primarily built to support industrial growth [2] by spurring industrial growth [6] and efficient resources usage [5] while also aimed to protect the environment [3]. Based on their purposes, industrial estate firms becoming important for a nation and need to be sustained. However, along their lifespan, industrial estate firm will then follow the firm life cycle pattern [7].

Following the common firm life cycle, industrial estate firms will experience profit ups and downs [8]. At the beginning of the firm life cycle, industrial estate firms have land and building to be sold, thus they will be able to make enough profit. However, along the time period, if the business runs well, these land and buildings will eventually be sold out. Thus, in the later stages, industrial estate firms need to find other sources of profit to keep them 


\section{Wirawan, et al. / Advances in Science, Technology and Engineering Systems Journal Vol. 3, No. 5, 128-139 (2018)}

sustained. Many industrial estate firms have tried to sustain by expanding the industrial estate of building another one in a different location. But this strategy seems to be unsuitable for longterm business since the land will eventually run out and the industrial estate market will also be saturated. Moreover, the local government will also impose several regulations that will limit the building of industrial estate firms. Then, to help industrial estate firms to be sustained, the concept of PSS is seemed to be suitable.

PSS concept attempt to shift tangible products consumption into services with the same performance, function, and benefit [9]. By applying the concept of PSS, the production and consumption of tangible products can be reduced so as to reduce the environmental burden, providing opportunities for new business models [9,10], and improving the social conditions of the community through co-creation [11]. According to experts, PSS is divided into three types and for each type of there are several types of business activities. In its implementation, the company can choose the type of PSS and business activities. Each type and business activities have their own characteristic that will build different strategies. These strategies would be suitable with the condition of the industrial estate firms at each stage of the life cycle. The appropriate business activity at the beginning of the life cycle stage may be different from the appropriate business activity at the later life cycle stages. The concept of PSS that combines the tangible products with services is considered to be suitable for the firms to achieve sustainability in each stage of its firm life cycle. It can be achieved by combining the limited tangible products with services.

In Indonesia, the first industrial estate was built in Cilacap in 1968 and the number was continuously increasing each year. The rapidly increasing number of industrial estate firms is partly due to the fact that since 1989 the private sector has been allowed to build industrial estate firms in Indonesia. Until now there are about 232 industrial estates in Indonesia [12]. About 68.24\% industrial estates were located in Java, the most populous and developed island in Indonesia, where Jakarta as Indonesian capital is also located [12]. Therefore the Indonesian government encourages further industrial estates development outside of Java [13]. This regulation is applied to increase the distribution of industrial, economic and welfare development, especially outside of Java [12].

In Indonesia, the importance of industrial estate roles is strengthened by the Constitution of Republic of Indonesia number 3 the year 2014 (Undang-Undang Republik Indonesia) on the industry, which states the development of the industry as one of the pillars of national economic development [14]. Indonesian industrial estates were built to support national industries. According to Indonesian government's regulations, industrial estates in Indonesia were built for several purposes, such as to accelerate the spread and equality of industrial development; to develop environmentally friendly industrial development; to encourage investment and industrial competitiveness; and to give certainty to the site [15]. With these regulations, it is obvious that industrial estate firms play important roles to support economic development [14] through raising companies efficiency; attract investors [16]; create job opportunities; foster innovation [3]; and support welfare enhancement in surrounding area. Industrial estates also help the government to control environmental impact and industrial development [15]. Considering the importance of the roles of industrial estate companies, it is necessary to think applicable efforts to support their sustainability.

The Indonesian government has already been aware of the important role of industrial estate firms by encouraging industrial estate firms' performance and the effort for sustainability. One of the efforts done by Indonesian government is by setting government regulation in 2009 and 2015 that remark sustainability in term of economic [14-15,17] and competitiveness; social [17]; community [6]; and environmental [15,17] which are deemed suitable with sustainable development concept [18]. As an effort to improve the performance and sustainability of industrial estates, Indonesian government through The Indonesian Industrial Ministry holding Indonesian Industrial Estate Award(s), which has been held at 2013 and 2015 [17].

Indonesian industrial estate firm will also face a life cycle pattern problem, which in a certain period they will experience a decrease in profit due to exhaustion or reduction in product sales. But given its important role, they need to be sustainable. As discussed previously, the PSS concept would be necessary to help industrial estate firms to be sustained.

There have been many studies and discussions about PSS related to the life cycle carried out by researchers. Most researchers write about PSS to prolong product and PSS life cycle and further to recycle or rebuilt them.PSS concept discussed managing PSS product life cycle stages: design, manufacturing, usage, remanufacturing or disposal [19-20] toward sustainability. While for of PSS life cycle, PSS management discussed for the beginning of life, middle of life and end of life [20-21]. Beginning of life stage consist of ideation, requirement, design, middle of life consist of realization, delivery, support, and end of life consist of evolution $[20,22]$.

However, the article that discussed PSS management to address the firm life cycle has not been found. Although commonly the pattern of product, PSS, and firm life cycle may be similar, the strategy to manage the PSS would be different due to the unique characteristic of each industrial estate firms. The article discusses the implementation of PSS at industrial estate firms has also could not be found. Therefore, this article will discuss PSS implementation at industrial estate firms.

As pointed earlier, this article is an extent of our previous work. In the previous work, we found that Indonesian industrial estate began to lead to the provision of services, in addition to merely selling products [1]. They already practice some of the business activities as an effort to gain new profit toward sustainability [1]. This article will extend the finding by considering the firm life cycle. Relation of the type of PSS and business activities practiced with the stages of the firm life cycle would be studied. This study is conducted due to the fact that for industrial estate firm, there are different characteristics in each stage of the firm life cycle that will logically differ on what are the suitable type of PSS that need to be implemented.

The objective of this article is to build a conceptual framework regarding sustainable issues of industrial estate firms in each stage of firm life cycle using the PSS concept. This article will study each PSS types and business activities implementation at 5 industrial estates firms to understand PSS implementation in 


\section{Wirawan, et al. / Advances in Science, Technology and Engineering Systems Journal Vol. 3, No. 5, 128-139 (2018)}

Indonesian industrial estate firms while testing the theoretical based framework. This article will contribute to help industrial estate firm by raising awareness and giving suggestion to the industrial estate firms so that they will be more focus on providing services as the alternative income generator. This article also highlights the differences of PSS concept that is needed among stages of firm life cycle to help industrial estate firms sustain in each stage. For the government, this article will give insight for industrial estate planning and policy-making to encourage sustainability of the industrial estate firms to suitably play important roles. For academic field, this article will contribute to combine PSS concept with life cycle concept in an effort to help industrial estate firms to sustain.

In the following section, the literature review will be discussed, especially about the concepts that will be used as the basis for the formation of the framework and the previous studies followed by the research objective and methodology. Furthermore, the conceptual framework of PSS management will be presented at each stage of product life cycle followed by a discussion on PSS management framework and practice in Indonesian industrial area. In the end, this article will be closed by the conclusion, including implications and further research directions.

\section{Literature Review}

As previously mentioned, in most countries, industrial estates managed by industrial estate firms, have been built to help companies to operate more efficiently due to they are providing facilities, amenities, and waste treatment infrastructure to support companies' in their operation [4,5]. Industrial estates are built with the objectives to encourage employment rate and economic growth [6,23], to attract new firms [5] and foreign direct investments [6], to foster technological learning and innovation [3], to spur an industrial dynamic [6], to efficient resource used, and to lower environmental burden [23]. With this supports, companies may benefit from the reduced cost of getting water, energy, material, etc., as well as disposal cost [24]. Another benefit that will be gained by the company is an opportunity to build relationships and make collaborations with other companies and stakeholders to build value co-creation [25].

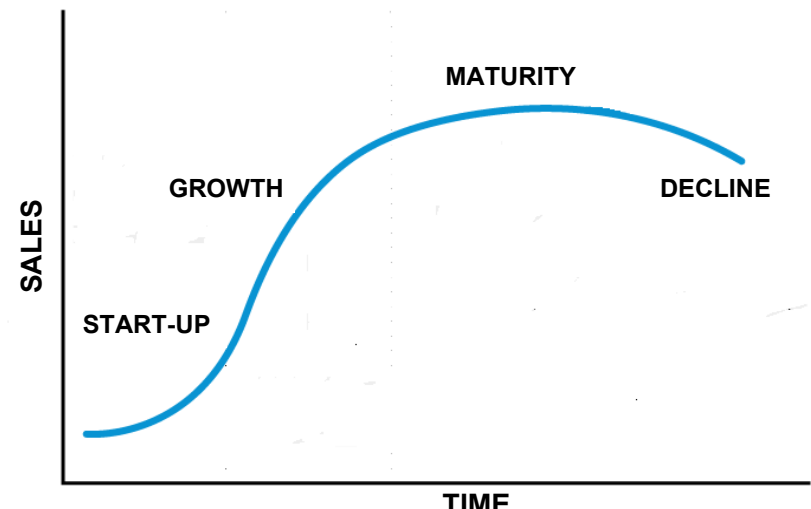

Figure 1. Common life cycle model[8], [26]

In the course of their growth and development, firms will experience the stages that form the general pattern, namely the firm life cycle [7]. Several authors identified divisions of firm life cycle stages. However, common stages are divided into start-up, growth, maturity and decline stages [26] with the S-shaped pattern [27]. The common pattern of the life cycle is as shown in Figure 1 [8,27]. At each stage of its life cycle, the company will experience different conditions of different pressures, threats, and opportunities [28]. Therefore, the company will need a different strategy and performance [29], structure [30], effectiveness criteria [31], profit-maximizing [27] to keep sustaining in each stage of the life cycle.

In Indonesia, industrial estate firms have an important role in national economic development. This is indicated by the Republic of Indonesian government regulation requiring industrial companies to operate within industrial zones administered by licensed industrial estate companies, except in limited circumstances [15]. While in Indonesian republican law, the industry is declared as one of the pillars of national economic development [14]. Thus, it is clear that the industrial estate firms have an important role to play in national economic development. Indonesian Ministry of Industrial and Trade at 1987 already stated that industrial estate firms have obligations to provide road network in industrial estate, drainage, installation of clean water supply along with distribution channels to each industrial plot, wastewater treatment plant which can accommodate all wastewater from factories in industrial estates, electricity supply installations and distribution networks, telecommunications networks, environmental impact control facilities, lighting, industrial estates corporate offices, fire-fighters, housing for industrial workers, social and public facilities in accordance with the relevant provisions of the relevant agencies [12]. The Indonesian government already paid attention to the importance of industrial estate firms, as well as efforts to support the Indonesian industrial estate firms' sustainability by issuing some regulations, such as that remark sustainability in term of economic [14-16] and competitiveness [17]; social [17]; community [6]; and environmental $[15,17]$ which are deemed suitable with sustainable development concept [18], as well as formulating a roadmap for industrial estates and organizing industrial estate awards for high performer industrial estates [17].

The first industrial estate in Indonesia was built in Cilacap in 1968, and since then some new industrial estates are built each year and the number increases from year to year. Until now, prospects for industrial estates is still considered good since demand is rising [12]. Geographically, the industrial area in Indonesia is still not evenly distributed. Most of them or as much as $68.24 \%$ have been built on Java, while in Riau Island, Riau and Bintan is 17,17\% [12]. In Sumatra, Kalimantan, Sulawesi, Ambon and Papua there are $7,73 \%, 3.43 \%, 2.58 \%, 0.43 \%$ and $0.43 \%$ respectively [12]. Java is attractive to industrial estate firms due to the density of the population thus able to provide advantages of localization and urbanization economy[32]. Moreover, the complete facilities and infrastructure in Java and the presence of the nation's capital making it more interesting for further gain on profit. With this condition, the Industrial Master Plan or RIPIN 2015-2035 prioritizes the development of industrial areas outside Java to encourage welfare distribution throughout Indonesia.

Indonesian industrial estate firm main business is selling products in the form of land and buildings that make most of the profits. In addition, industrial estate firms also provide a range of services to support and to assist companies in the industrial estates 


\section{Wirawan, et al. / Advances in Science, Technology and Engineering Systems Journal Vol. 3, No. 5, 128-139 (2018)}

such as renting warehouses, land, buildings, industrial vehicles and other industrial equipment; providing water supply, waste treatment, and disposal; shipping and delivery facilities, etc. [1]. Product in the form of land and building usually give enough profit for industrial estate firms, but it is still limited. Once the land and buildings are sold out, the profits will only come from the provision of services, which is, of course, lower than the sales of the products. Some industrial estate firms maintain their sustainability by expanding the land or opening industrial estates elsewhere. However, this strategy cannot be done continuously since in the near future, the land will run out. This condition is also barred by the limitation by the rules of fringe benefit that some allocated area is not supposed to be used for industries [33]. Therefore, a new business model that emphasizes the provision of services will be appropriate to be applied to industrial park companies in order to remain profitable enough to be sustained.

Related to the firms' life cycle concept, in the early stages of its life cycle, industrial estate firms will gain enough profit from product sales, but in the later stages where the product is sold out, the industrial estate company needs to find a new business model to earn enough profit to be sustained. Regarding the importance of the role of industrial estate companies in Indonesia in contributing to the development of the national economy, an effort to maintain their sustainability is highly needed. The concept of PSS that combines product sales and service provision will be suitable for application in industrial estate firms, especially in the later stage of the firm life cycle.

PSS is a system of products; services; network; and infrastructure designed to meet customer needs and cause lower environmental impact than traditional business models while seek to increase firm competitiveness [34]. PSS promote dematerialization $[9,35]$. It is the attempt to decrease tangible products consumption, and wherever possible change it into the bundle of products and services [9]. PSS also attempt to tangible products' useful life and increase the utilization of tangible products [10] that both will reduce tangible product usage. With PSS concept, consumer or user will receive relatively equal function, performance, and benefit as they buy tangible products in a different way. PSS concept attempt to decreased environmental burden and meeting the needs of the world's population that increased dramatically caused by the sharp increase in population and consumption of large quantities of products in recent decades [9].

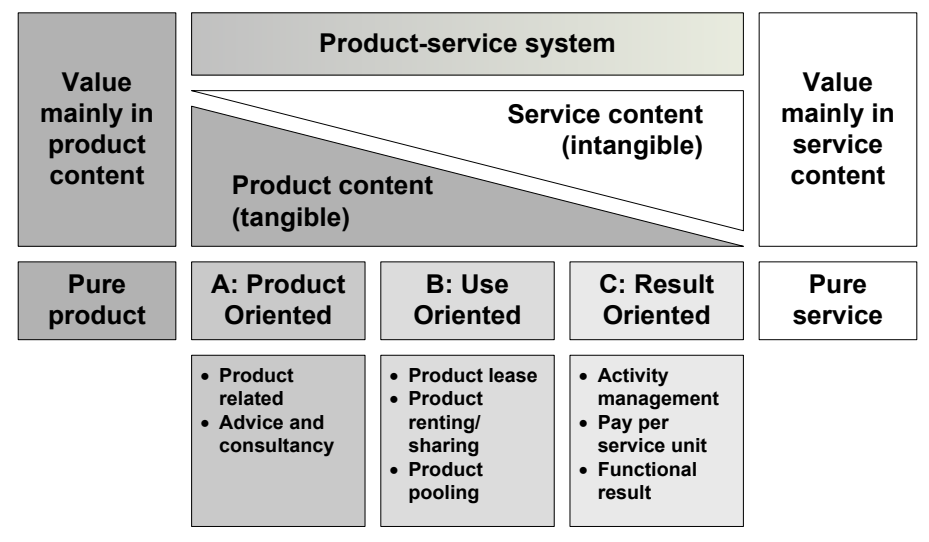

Figure 2. Types of Product-Service System (PSS) [35]
To attain their sustainability, PSS would be appropriate to implemented by industrial estate firms since it brings out an opportunity to find new added value and competitiveness. PSS can also increase customers' satisfaction by offering customized product and services, building a good customer relationship, and creating faster innovation opportunity [35]. All of these conditions can lead industrial estate firm to gain competitive advantage and then sustainability. A reference [36] stated that land and building selling in industrial estates need to be shifted into services in the future because of the availability of the limited products.

According to experts, the PSS is categorized into three different types, namely product-oriented, use-oriented, and resultoriented $[10,36]$ as shown in Figure 2. Each of the type related to particular business activities and particular composition of products and services.

The first type is Product-oriented PSS. Product-oriented PSS is the type of PSS that most closely resembling a traditional business, where products ownership transferred to the customer as the main business, but with the addition of services to extend products' life and retrieve them when the product is unusable for recycling[10]. Reference [35] stated 2 business activities of product-oriented PSS, namely product-related services and also advice and consultation to prolong the product's useful life as an effort to decrease the product consumption [35]. Example of product-oriented PSS implementations in industries is Eastern Energy, which provides energy management; consumption and process monitoring; utility awareness; and training to help their customer maintain the products that will prolong their life cycle [10]. The other example is Polyplank AB that creates cheap, recyclable and moistureresistant composite material to be used for paper mill's core plug from plastic waste [37]. Polyplank AB also takes back the core plug to be reused four times before need to be replaced [37]. With this system, products consumption can be reduced.

The second type is use-oriented PSS. The Use-oriented PSS is a PSS type in which the tangible product is used, but the ownership of the product is not transferred to the customer for the purpose of improving the utilization and extending the useful life of the product [10]. Business activities in this type are product lease, product renting/ sharing, and product pooling [35]. Examples of this type are vehicle sharing group, where vehicle provided by the provider and used by several customers by sharing scheme [10]. In Seoul, a public bicycle system operated to reduce energy consumption, raise community health status as well as reduce bicycle used and budget for buying bicycle by individuals [38]. The other example is Conway's water purifier which built a rental system with the regular visiting maintenance service for water purifier [39]. With this rental system, the customer does not need to buy the product, and other customers can use the product when he/she does not intend to use it. Regular visiting of maintenance will help the product to be in good condition and can be used for a longer time.

The last type is result-oriented PSS. Result-oriented PSS is the type of PSS with the greatest service composition. In this type, customers buy services in the form of capabilities and results [10]. Business activities in this type are activity management, pay-perservice unit, and functional result [35]. Example of this type o PSS implementations is Xerox pay-per-copy system, where the 


\section{Wirawan, et al. / Advances in Science, Technology and Engineering Systems Journal Vol. 3, No. 5, 128-139 (2018)}

customer will lease the copy machine and they will pay per copy they made counted by the machine [10]. Xerox will also provide maintenance service and will take the machine back after the leased in finished. With more or less similar system, Electrolux also create a system, which customers pay initial fee for placing the washing machine in their place, then payment would be made per wash [10]. Electrolux also is responsible for the maintenance, reparation, and another financial service of the washing machine [10]. With this system, the washing machine useful life will be prolonged, since the cost for maintenance and repair done by the experts, while customers benefit from efficient cost.

Among these three types of PSS, there would be differences in product and service proportion, as well as business activities. Product-oriented PSS has the largest proportion of the product, followed by the use-oriented PSS, thus conversely, result-oriented PSS has the largest service proportion. Business activities of each type of PSS would be appropriate to be applied at each stage of the firm life cycle of industrial estate firms to help industrial estate firms to be sustained in each stage of the life cycle.

This article will discuss the conceptual framework of PSS management at each stage of the firm life cycle. The discussion will take the context of Indonesian industrial estate firms that have important roles in Indonesian economic development as stated in the Indonesian Constitution Number 3 the year 2014. This article will provide a novelty on the application of PSS types at the stages of the firm life cycle within the context of industrial estate firms in Indonesia.

\section{Research Objectives and Methodology}

From the beginning, the Government of Indonesia built industrial estate firms with the main objective of controlling industrial development, controlling the environmental burden, overcoming the limitations of industrial support, and accommodating housing needs around industrial sites [36]. Later on, the purpose of an industrial estate building is growing primarily to develop the industry [36] in an attempt to support national economic growth [14]. Different from most countries, starting from 1989 until now, industrial estates in Indonesia are allowed to be built by the private sector [36]. With this permission, industrial estates in Indonesia are developing even faster. The fast development is due to capital addition and new innovation from private firms. In future development, industrial estates in Indonesia are directed and expected to adopt the concept of a modern industrial estate for the development of a sustainable national industrial competitiveness [36]. In addition, they are also expected to contribute to aspects of sustainability, namely economic, social, and environmental development [36]. The future development of Indonesian industrial estates is also directed at providing services rather than merely selling products [36].

This article will use the PSS concept to help Indonesian industrial estate firms that play important roles in national economic development to gain enough profit and can be sustained in each stage of the life cycle. According to the previous research, actually Indonesian industrial estate firms are starting to do business activities that match with PSS concept [28]. This finding indicates that Indonesian industrial estate firms are suitable for PSS implementation. Therefore, this article will provide a conceptual framework to manage PSS in each stage of the industrial estate firms' life cycle to sustain the industrial estate firms. This article will also provide direction for relevant further research. The conceptual framework also attempts to help the Indonesian government to set a plan, policy, and regulation that will be suitable for the industrial estate firms' development.

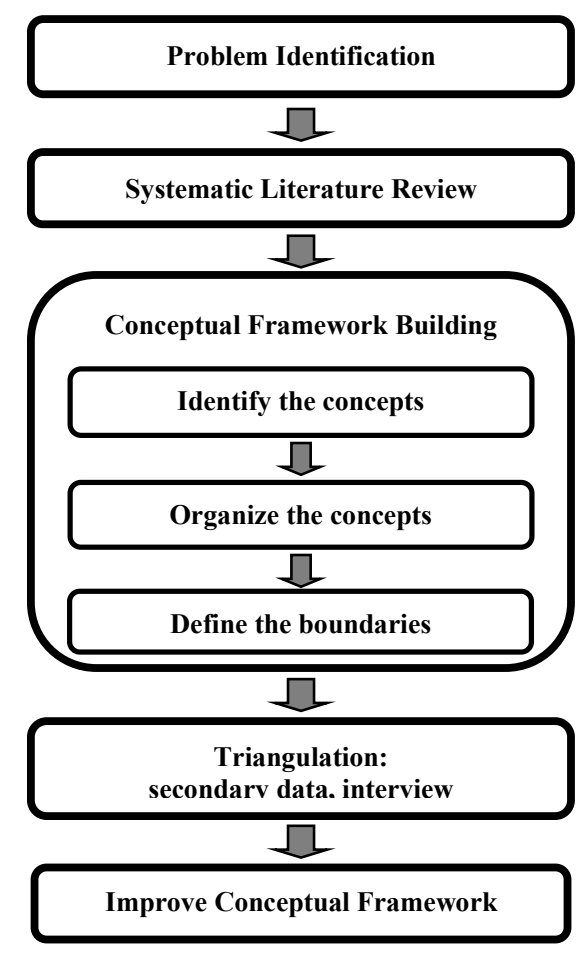

Figure 3. Conceptual Framework Building

To create the conceptual framework, deductive and inductive approach used as shown in Figure 3. A deductive approach will be used to build the framework based on literature reviews while inductive approach will be used to test and improve the framework.

The research begins by identifying problems by examining the condition of industrial estates in Indonesia. Next, authors conduct a systematic literature review on the industrial estate, firm life cycle and PSS to find suitable concepts to build the conceptual framework. The conceptual framework then was built deductively. To build the conceptual framework, there are several methodologies known. This article uses a methodology that suggests three steps of conceptual framework building: (1) identify the concepts, (2) organize the concepts, and (3) define the boundaries [40]. After that, some cases of industrial estate firms will be used to test the conceptual framework. The data will be obtained from secondary data from websites and results. The framework testing will use an inductive approach. The conceptual framework would be improved if needed based on the test result.

To test the conceptual framework, 5 industrial estate firms would be obtained. Four of them are 2015 industrial estate awards winners, namely First Industrial Estate, Second Industrial Estate, Third Industrial Estate, and Fourth Industrial Estate. Industrial estate awards event was conducted in 2015 by Indonesian Industrial Ministry especially to monitor industrial estate development. These industrial estate firms were chosen because they are well-established, good performers and already proven their performance and sustainability for about 30 years. One of the 


\section{Wirawan, et al. / Advances in Science, Technology and Engineering Systems Journal Vol. 3, No. 5, 128-139 (2018)}

industrial estate firms taken is the latecomer or new industrial estate firms, namely Fifth Industrial Estate. This industrial estate firm is taken to compare the condition with the four wellestablished industrial estate firms. Interviews were conducted with experts whose are works in industrial estate firms and consultant of industrial estate firms. The names of the industrial estate firms are disguised in this article, to maintain the confidentiality of the firms.

PRODUCT-SERVICE SYSTEM

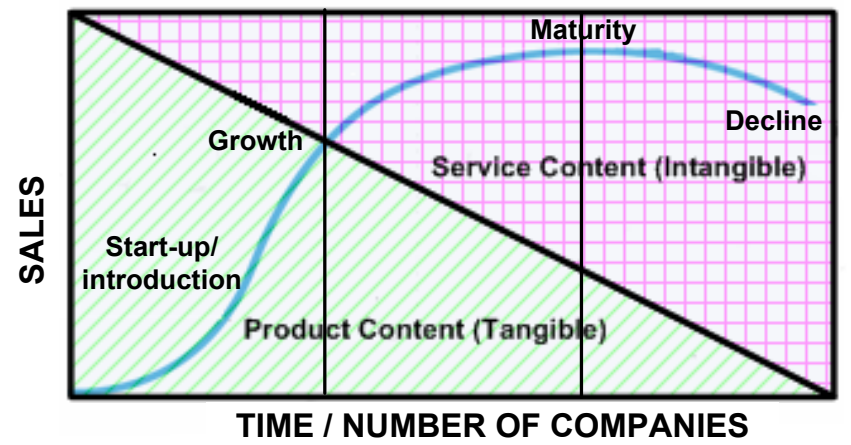

\begin{tabular}{|c|c|c|}
\hline $\begin{array}{c}\text { PRODUCT- } \\
\text { ORIENTED PSS }\end{array}$ & $\begin{array}{c}\text { USE-ORIENTED } \\
\text { PSS }\end{array}$ & $\begin{array}{c}\text { RESULT- } \\
\text { ORIENTED PSS }\end{array}$ \\
\hline $\begin{array}{l}\text { - Product related } \\
\text { Sell products, } \\
\text { such as land, } \\
\text { buildings, } \\
\text { equipments, } \\
\text { vehicle } \\
\text { Provide } \\
\text { maintenance, } \\
\text { repair, and } \\
\text { supplies services } \\
\text { - Advice and } \\
\text { consultancy } \\
\text { Advice about } \\
\text { maintenance and } \\
\text { product usage } \\
\text { Consultancy } \\
\text { about product } \\
\text { usage or } \\
\text { efficiency }\end{array}$ & $\begin{array}{l}\text { - Product lease } \\
\text { Lease products } \\
\text { with unlimited } \\
\text { access, such as } \\
\text { land, buildings, } \\
\text { machinery } \\
\text { Provide } \\
\text { maintenance, } \\
\text { repair, and } \\
\text { supplies services } \\
\text { - Product renting/ } \\
\text { sharing } \\
\text { Rent and share } \\
\text { products with } \\
\text { limited access, } \\
\text { such as } \\
\text { equipments, } \\
\text { vehicles } \\
\text { Provide } \\
\text { maintenance, } \\
\text { repair, service } \\
\text { Product pooling } \\
\text { Rent products to } \\
\text { be used together } \\
\text { by customers } \\
\text { simultaneously, } \\
\text { such as packing } \\
\text { equipments, } \\
\text { delivery } \\
\text { equipments } \\
\text { Provide } \\
\text { maintenance, } \\
\text { repair and } \\
\text { service }\end{array}$ & $\begin{array}{l}\text { - Activity } \\
\text { management } \\
\text { Provide various } \\
\text { services that will } \\
\text { support } \\
\text { customers with } \\
\text { outsource } \\
\text { system with } \\
\text { regular periodical } \\
\text { payment, such as } \\
\text { security services, } \\
\text { cleaning services } \\
\text { - Pay per service unit } \\
\text { Provide various } \\
\text { output of } \\
\text { products and } \\
\text { services with } \\
\text { payment per } \\
\text { output taken by } \\
\text { companies, such } \\
\text { as copy machine, } \\
\text { washing machine } \\
\text { - Functional result } \\
\text { Provide comfort } \\
\text { office, company } \\
\text { environment, fast } \\
\text { delivery, etc }\end{array}$ \\
\hline
\end{tabular}

Figure 4. Conceptual Framework of PSS Management

\section{Conceptual Framework}

As discussed earlier, the problem faced by Indonesian industrial estate firms is how to sustain at every stage of the firm life cycle. Based on this problem, systematic literature reviews were conducted to build the conceptual framework. The first step in building a conceptual framework according to the chosen methodology is to identify the concepts. From the literature review, observation, and interview, it is found that industrial estate companies experience the firm life cycle pattern [41]. At the initial stage of the life cycle, industrial estate firms gain enough profit from selling the product in the form of land and building. But after that, the profit will be decreased because the land and building would be sold out.

Some of Indonesia's long-standing industrial areas maintain their sustainability by expanding and/or creating new business models based on services. The literature review is also carried out to find a suitable concept to help industrial estate companies to be sustainable at each stage of the firm life cycle. The literature review found that the article that links between PSS with the firm life cycle is still rare. In addition, articles on the application of PSS to industrial estate companies have not been found. Therefore, this article will try to apply the concept of PSS related to the life cycle of the company in the Indonesian industrial estate firms. The concept of PSS is found to be appropriate to address this problem, as it offers a new business model that combines products with services. Then it can be concluded that this article will use the concepts of industrial estate firms, firm life cycle, and PSS.

The second step is to organize the concepts. As discussed previously, Indonesian industrial estate firms will generally follow the firm life cycle [41] although the details of the form and the pattern period may be different from the common pattern. Then to be sustained at each stage of the life cycle, the firms need to apply particularly suitable strategies [29]. Considering the characteristics of industrial estate firms that have limited tangible resources, the PSS concept that seeks to shift the use of products to services will be appropriate. The concept of PSS consists of 3 types, each of which consists of different business activities to shift the consumption of products into services [35]. Each of these types of PSS can be implemented as a strategy at each stage of the product life cycle in an attempt to be sustained. For example, for the introduction and growth stages, product-oriented PSS would be suitable, because mostly in these stages industrial estate firms sell products. But this is not the case for other stages. The relationship of the concepts built the conceptual framework for industrial estate firm as described in Figure 4.

This figure shows that in course of their life, industrial estate firm, as also most firms, will face stages of firm life cycle, namely startup/introduction, growth, maturity, and decline [8]. Due to the limitations of products to be sold, then in the early stages of the firm life cycle, industrial estate firms can sell more products than services. However, in the later stages, when the product is sold out, in order to sustain they need to provide more services. This condition is matching with the characteristics of the PSS types' distribution, namely product-oriented PSS, use-oriented PSS, and result-oriented PSS. Industrial estate firms can appropriately apply product-oriented PSS in the early stages of the product life cycle, where they still have products to sell or product sales are still increasing. After that, use-oriented PSS will be appropriately applied, when the product starts to run out or product sales begin to decline. At last, result-oriented PSS will be appropriate to be applied when the product is fewer or even exhausted and product sales are declining significantly, so new income from the new business model is needed. With the new business, the industrial estate will be survived even in decline stage.

For each type of PSS, there are business activities that can be implemented by the firms. Using the product-oriented type, most firms sell product and added services [35]. Most Indonesian 


\section{Wirawan, et al. / Advances in Science, Technology and Engineering Systems Journal Vol. 3, No. 5, 128-139 (2018)}

industrial estate firms' core business is selling products in form of land and buildings. Some industrial estate firms also sell supporting facilities and equipment, but usually, this is not the core business. Service provided by the firms that accompanying product, mainly with purpose to prolong its useful life, in form of:

(1) Product-related services. The business activity where firms sell products to the customer but also add services to prolong the product's useful life, efficient use and take back after usage [35]. Industrial estate firms provide maintenance, repair and supplies services for companies' land, buildings, and facilities, such as the industrial vehicle; machinery; waste; water treatment, etc.

(2) Advice and consultancy. The business activity where firms give advice and consultancy regarding companies operations, management or setup to help prolong the product's useful life and efficient use [35]. In these business activities, the industrial estate firms can provide assistance in form of providing training and consultancy for several activities, such as inventory control, company setting, organizational management, waste treatment, maintenance, etc.

Using use-oriented type, firms sell the use or availability of product [10] instead of sell product [35]. Indonesian industrial estate firms' do business activities of this type in form of :

(1) Product lease. The business activity where firms lease products instead of selling them [35]. Products ownership would still be at producer instead of customer [35]. The producer also has responsibilities of maintenance and taking back products at the end of its useful life [35]. With this business activity, customers get unlimited access to the products leased [35]. Industrial estate firms can lease land; building; industrial vehicles; warehouse; and other equipment to customer/user. Customer/user can use and access the products unlimitedly during the period of leasing. Hence, customer/user is defined as industrial companies operated in the industrial estates firms. Companies, as the customer/user, pay regular fee periodically, while maintenance and repairment ensured by industrial estate firms. This action will ensure cost-efficiency in the whole industrial estate firms due to economic scale and utilization.

(2) Product renting or sharing. The business activity where customer/user rent products and the products can be used by more than one customer [35]. Here, customer/user does not have unlimited access [35]. Industrial estate firms can provide facilities, such as a warehouse, office building, and equipment, such as the vehicle, and machinery to be rent to companies. Customers can share in using these products with other. Industrial estate firms can also rent it to more than one customer with the particular arrangement. This scheme will increase the utilization and productivity of products, decrease total products produce, as well as benefit the customer at an efficiency, practical and lower cost.

(3) Product pooling. The business activity where products can be used together and be operated for more than one customers simultaneously [35]. Industrial estate firms can provide some industrial vehicles, equipment, and facilities that can be used by customers simultaneously. For instance, to deliver production results, more than one customers can use the same vehicle. Another example is water treatment, which more than one customers can use the same equipment. This scheme would be applicable for industrial vehicle and equipment. However, for land, buildings, and specific machinery this scheme will only be applicable for companies that only need the products occasionally or operated in a low capacity.

Using the result-oriented type, the firm sells result or capability instead of products, that can be customized to what customers/users needs [10]. Customers/users will then pay only for the result used [10]. Industrial estate firm can do business activities in form of:

(1) Activity management/outsourcing. The business activity where firms provide outsourcing for customers [35]. Industrial estate firms can provide various services that will support customers to operate more efficiently. Some services that can be provided are cleaning services; garden maintenance; security services, etc. Customers may use those services with the particular amount of payment included in the contract. With this business activities, customers can focus on their own core business, and do not need to waste much energy and effort to manage the supporting activities and the workforce who carry it out.

(2) Pay per service unit. The business activity where firms provide services for customers that are charged per services used by the customer [35]. Industrial estate firms can provide document center; food service; laundry service; load or unload service; and transportation service. Customers can use the services by paying the result according to the number of output needed and used. With this business activity, customers will benefit from efficient cost spent on facilities that actually not continuously or intensely used.

(3) Functional result. The business activity where firms sell functional results instead of products [35]. Industrial estate firms can provide results as services for customers, such as a clean working space; comfortable office; healthy worker; skillful worker, etc. Customers will only pay for the results and get the benefit, without the need to manage or have the skill to do the process by themselves.

The third step of conceptual framework building is to define boundaries. This conceptual framework will be build for Indonesian industrial estate firms because the data were taken from Indonesian industrial estate firms. The basic concept would be compatible for industrial estate firms in other countries but the data must be obtained to adjust whether there are differences in the regulations, conditions, roles, and characteristics of industrial estate firms.

The next step is framework testing to confirm the deductive conceptual framework. Framework testing will be conducted using official websites, papers, and interviews with experts as summarized in Figure 4.

\section{Result and Discussion}

Indonesian government issuing regulation that industrial estate firms have obligation to provide at least: (1) standard water treatment installation; (2) sewage water treatment installation; (3) drainage; (4) street-lighting; (5) and road for the companies operated in the estate[15]. Then we can conclude that these are the minimum requirement of industrial estate firms. In Indonesia, 


\section{Wirawan, et al. / Advances in Science, Technology and Engineering Systems Journal Vol. 3, No. 5, 128-139 (2018)}

according to several sources, it is known that most industrial estate firms depend so much on products selling since it gives large enough profit compares to providing services.

To investigate the implementation of types of PSS and their business activities in Indonesian industrial estate firms, data were obtained from the official websites, the papers, and interviews with experts that closely related to industrial estate firms. As mentioned before, in this article we study 5 industrial estate firms to test the framework. The first four industrial estate firms are 2015 industrial estates award winners whose operated about 30 years, and the fifth is a new industrial estate firm, operated below 5 years. The first three industrial estate firms are located in Java island and the last two are outside Java island.

From our study, we found that all industrial estate firms studied already fulfilled, even exceed, all standards determined by the government. They already provide water supply, water treatment and waste treatment services, security, lighting, road and network, and other infrastructure. The industrial estate firms also found already doing business activities in types of PSS, as summarized in table 1 .

From the data, we found that all industrial estate firms studied are focus on selling land and/or buildings as their main business in the early firm life cycle period. Beside selling land and/or buildings, all industrial estate firms also provide maintenance and security services to help customers in operating their businesses. Additionally, the fourth industrial estate provides consultancy and advice services to assist companies (as customers) that will invest in the industrial estate, and assist license application. The fifth Industrial Estate also provides 3 hours investment licensing system to ease companies joining the estate. This fact has proven that Indonesian industrial estate firms in the early stage of life cycle already implement business activities that comply with productoriented PSS.

Although all industrial estate firms implement product-related business activities, the fourth industrial estate, and the fifth industrial estate also provide implementation advice and consultancy. Among the industrial estate firms, it is found that the kind of services and products provided are almost the same. All of them get the most profit that comes from selling products and provide services in form of maintenance, repair, and security. The fourth industrial estate and the fifth industrial estate have uniqueness in form of license application assistance that maybe become the competitive advantage.

As mentioned in table 1, all industrial estate firms provide warehouses for lease, while the first industrial estate and the second industrial estate also lease factories to customers and the fifth industrial estate rent tank farms. This fact shows that all industrial estate firms already implement product lease business activity with almost the same kind of services. The third industrial estate found rent vehicle, while the fifth industrial estate plan to built meeting incentives, convention, and exhibition (MICE) facility. In many countries, MICE recently believed can attract visitors and bring economic benefit, raising good image, and have a positive impact on the development of the local region as well as the country.
Due to implementing and planning rent business activities, the third and the fifth industrial estate already implement the product rent/sharing business activity. All industrial estate firms provide logistic service with pool system. Additionally, the second and the fifth industrial estate provide a dry port facility that can ease and fast the distribution process. This condition shows that the first to the fourth industrial estate already implement use-oriented PSS through the business activities. Whereas the fifth industrial estate as the considerably new industrial estate has also implement useoriented PSS, although some activities are still in the planning phase. In use-oriented PSS, it can be seen that there slightly different services provided by industrial estate firms. The differences mainly because of difference in resource and capability owned by the industrial estate firms.

The third industrial estate provides custom office in the estate, while the fourth industrial estate provides manpower management and recruitment service and provide immigration clearance to help companies in the estate. The second industrial estate provides security, office boy and cleaning service outsources, managed by the industrial estate firm. Paying periodical fee, companies in the estate can use these outsourcing services. These services show that the industrial estates already do management business activity, helping customers to do their non-core business with outsourcing system. The first to the fourth industrial estate already do pay per service unit business activities, while the fifth industrial estate still finds the one pay per service business activity. All industrial estates provide hotel. The first to the fourth industrial estate provide health service. The unique pay per services business activity provided by the second industrial estate by renting helicopter; the third industrial estate by providing vehicle service; and the fourth industrial estate by providing dormitory and executive village. Furthermore, the first to the fourth industrial estate already do functional result business activity. The first to the fourth industrial estate provide commercial facilities or shop houses and sport and entertainment facilities, while the first and the second industrial estate build a city around the industrial estate, the second and the third industrial estate build educational facilities, and the second industrial estate built senior living facility. The fifth industrial estate plan to build community academy, but the training already conducted for Sei Mangkei's human resource. From these business activity implementations, it can be concluded that the first to the fourth industrial estate firms already implement resultoriented PSS, while the fifth industrial estate firm still starting to plan to implement result-oriented PSS, and already start to provide training. Based on the analysis, in result-oriented PSS, the difference of services provided even more. These difference can become the competitive advantage for each industrial estate firm.

All types of PSS already found in the first to the fourth industrial estate practice that means services already taken as an important point in their business. However, they were still emphasizing the limited land and building sales, especially during the early stages of their life cycle, since it is providing a great profit. That is why most industrial estate firms attempt to expand the land or find another location once the products sold out. This is due to the fact that selling products still becoming the greatest income generator for industrial estate firms. Nevertheless expanding the industrial estate not always a simple or possible option, because of the high investment and spatial regulation. On the other hand, they still have 
Table 1. PSS Implementation in Industrial Estate Firms

\begin{tabular}{|c|c|c|c|c|c|c|}
\hline $\begin{array}{l}\text { Types of } \\
\text { PSS }\end{array}$ & $\begin{array}{l}\text { Business } \\
\text { activities }\end{array}$ & $\begin{array}{l}\text { First Industrial } \\
\text { Estate }\end{array}$ & $\begin{array}{l}\text { Second } \\
\text { Industrial } \\
\text { Estate }\end{array}$ & $\begin{array}{l}\text { Third Industrial } \\
\text { Estate }\end{array}$ & $\begin{array}{l}\text { Fourth } \\
\text { Industrial } \\
\text { Estate } \\
\end{array}$ & $\begin{array}{l}\text { Fifth Industrial } \\
\text { Estate }\end{array}$ \\
\hline $\begin{array}{l}\text { Product- } \\
\text { oriented } \\
\text { PSS }\end{array}$ & $\begin{array}{l}\text { Advice and } \\
\text { consultancy }\end{array}$ & $\begin{array}{l}\text { - Sell land and } \\
\text { building } \\
\text { - Provide } \\
\text { maintenance } \\
\text { - Provide security }\end{array}$ & $\begin{array}{l}\text { - Sell land and } \\
\text { building } \\
\text { - Provide } \\
\text { maintenance } \\
\text { - Provide security }\end{array}$ & $\begin{array}{l}\text { - Sell land and } \\
\text { building } \\
\text { - Provide } \\
\text { maintenance } \\
\text { - Provide security }\end{array}$ & $\begin{array}{l}\text { - Sell land and } \\
\text { building } \\
\text { - Provide } \\
\text { maintenance } \\
\text { - Provide security } \\
\text { - Advice and } \\
\text { assist } \\
\text { companies on } \\
\text { incorporation } \\
\text { - Advice and } \\
\text { assist license } \\
\text { application }\end{array}$ & $\begin{array}{l}\text { - Sell land and } \\
\text { building } \\
\text { - Provide } \\
\text { maintenance } \\
\text { - Provide security } \\
\text { - Provide } \\
\text { assistance with } \\
3 \text { hours of } \\
\text { investment } \\
\text { licensing } \\
\text { service }\end{array}$ \\
\hline \multirow[t]{2}{*}{$\begin{array}{l}\text { Use- } \\
\text { oriented } \\
\text { PSS }\end{array}$} & $\begin{array}{l}\text { Product } \\
\text { renting/ } \\
\text { sharing }\end{array}$ & $\begin{array}{l}\text { - Lease } \\
\text { warehouses } \\
\text { - Lease factories }\end{array}$ & $\begin{array}{l}\text { - Lease } \\
\text { warehouses } \\
\text { - Lease factories }\end{array}$ & - Rent vehicle & $\begin{array}{l}\text { - Lease } \\
\text { warehouses }\end{array}$ & $\begin{array}{l}\text { - Lease } \\
\text { warehouses } \\
\text { - Lease tank } \\
\text { farms } \\
\text { - Rent meeting } \\
\text { incentives, } \\
\text { convention, and } \\
\text { exhibition } \\
\text { facility (in the } \\
\text { plan) }\end{array}$ \\
\hline & $\begin{array}{l}\text { Product } \\
\text { pooling }\end{array}$ & $\begin{array}{l}\text { - Provide Logistic } \\
\text { service }\end{array}$ & $\begin{array}{l}\text { - Provide logistic } \\
\text { service } \\
\text { - Provide dry port } \\
\text { facility }\end{array}$ & $\begin{array}{l}\text { - Provide logistic } \\
\text { service }\end{array}$ & $\begin{array}{l}\text { - Provide logistic } \\
\text { service }\end{array}$ & $\begin{array}{l}\text { - Provide logistic } \\
\text { service } \\
\text { - Provide dry port } \\
\text { facility }\end{array}$ \\
\hline \multirow{3}{*}{$\begin{array}{l}\text { Result- } \\
\text { oriented } \\
\text { PSS }\end{array}$} & $\begin{array}{l}\text { Activity } \\
\text { management }\end{array}$ & & $\begin{array}{l}\text { Provide } \\
\text { security, } \\
\text { cleaning } \\
\text { service, office } \\
\text { boy outsource }\end{array}$ & $\begin{array}{l}\text { Provide custom } \\
\text { office }\end{array}$ & $\begin{array}{l}\text { - Provide } \\
\text { manpower } \\
\text { management } \\
\text { and recruitment } \\
\text { service } \\
\text { - Provide } \\
\text { immigration } \\
\text { clearance }\end{array}$ & \\
\hline & $\begin{array}{l}\text { Pay per } \\
\text { service unit }\end{array}$ & $\begin{array}{l}\text { - Provide hotel } \\
\text { - Provide health } \\
\text { service }\end{array}$ & $\begin{array}{l}\text { - Provide hotel } \\
\text { - Provide health } \\
\text { service } \\
\text { - Provide } \\
\text { helicopter rent }\end{array}$ & $\begin{array}{l}\text { - Provide hotel } \\
\text { - Provide health } \\
\text { service } \\
\text { - Provide vehicle } \\
\text { service }\end{array}$ & $\begin{array}{l}\text { - Provide hotel } \\
\text { - Provide health } \\
\text { service Provide } \\
\text { dormitory } \\
\text { - Provide } \\
\text { executive } \\
\text { village }\end{array}$ & - Provide hotel \\
\hline & $\begin{array}{l}\text { Functional } \\
\text { result }\end{array}$ & $\begin{array}{l}\text { - Provide } \\
\text { commercial } \\
\text { facilities } \\
\text { - Provide sport } \\
\text { and } \\
\text { entertainment } \\
\text { facilities } \\
\text { - Built city }\end{array}$ & $\begin{array}{l}\text { - Provide } \\
\text { commercial } \\
\text { facilities } \\
\text { - Provide sport } \\
\text { and } \\
\text { entertainment } \\
\text { facilities } \\
\text { - University } \\
\text { - Built city } \\
\text { - Provide senior } \\
\text { living facility }\end{array}$ & $\begin{array}{l}\text { - Provide } \\
\text { shophouses } \\
\text { - Provide sport } \\
\text { and } \\
\text { entertainment } \\
\text { facilities } \\
\text { - Vocational high } \\
\text { school }\end{array}$ & $\begin{array}{l}\text { - Provide } \\
\text { commercial } \\
\text { facilities } \\
\text { - Provide sport } \\
\text { and } \\
\text { entertainment } \\
\text { facilities }\end{array}$ & $\begin{array}{l}\text { - Provide training } \\
\text { as an impetus of } \\
\text { community } \\
\text { academy }\end{array}$ \\
\hline
\end{tabular}

Source: summarized from official websites [42]-[45], a conference material [46]and interviews with experts

obligations to their customers as in the regulation that they still must manage the industrial estate and provide service to the companies inside. Therefore, they manage to provide various services to be sustained. The more they mature they will find more effort to innovate to provide more various services.
The first to the fourth industrial estate was built in the 1990s, range from 1989 until 1993. It means that they have operated more than 30 years and already in the middle or later stages of the life cycle. This is one of the reasons why their business activities tend to innovate in providing services. By providing more services, 


\section{Wirawan, et al. / Advances in Science, Technology and Engineering Systems Journal Vol. 3, No. 5, 128-139 (2018)}

industrial estate firms have more opportunity to do innovation. With innovation, firms have more opportunity to gain new profit to be sustained. In contrast to the four industrial estates that has long been operating, the fifth industrial estate has only been operating for about 3 years and still at the early stage of firm life cycle. So the fifth industrial estate still provides a little kind of service or still planning the services. This conforms with the framework that the more mature the industrial estate the more they need to provide service. It can be said that use-oriented PSS and result-oriented PSS would be needed when an industrial estate firm going to runs out their land and buildings to keep on sustain.

Among the industrial estate firms, while implementing product-oriented PSS, they mainly sell and provide similar products and services with similar business activities. Nevertheless, by using use-oriented PSS and moreover, result-oriented PSS, which is the composition of providing services more than products, among industrial estate firms there are differences in business activities and services provided. For example, there are industrial estate firms that rent factories, build a city, provide sport and entertainment facilities while the other create services such as healthcare, immigration clearance, etc. Then, it can be concluded that by providing more services, industrial estate firms can do more various business activities.

From the conceptual framework and discussion, there are propositions that can be built regarding PSS implementation in industrial estate firms toward sustainability, considering the firm life cycle.

Proposition 1: Industrial estate firm would need to provide more services in the later stage of the firm life cycle to be sustained because they have limited tangible products.

Proposition 2: PSS concept supposed to be suitable to be implemented for industrial estate firms, due to the emphasizes on services providing rather than tangible products.

Proposition 3: Among types of PSS, product-oriented, useoriented product-oriented composition of PSS is getting bigger, leading to more possibilities for innovation, as services are given more opportunity for it.

Proposition 4: More service composition leads to the industrial estate firms that have more flexibility to create business activities. That is why in the application of results-oriented PSS, there are many variations in the types of services provided between industrial estate firms. This variation can then become a uniqueness that will form a competitive advantage for industrial estate firms.

Proposition 5: In relation to Proposition 2, industrial estate firms with unique business activities and competitive advantage based on services will have the greater likelihood of profit and sustainability.

Proposition 6: All three types of PSS are appropriate to be applied to each product life cycle in order to maintain the sustainability of the industrial estate firm at each stage of the product life cycle. Product-oriented appropriate PSS is applied in the early stages of the company's life cycle when the firm is new and sells many products in the form of land and buildings. The appropriate use-oriented PSS is applied at the mid-life stage of a company when the product begins so little that the service has begun to be emphasized. Result-oriented PSS is appropriate to apply to the end of the firm life cycle when the product is getting smaller or exhausted, so the service needs to be the main business activity.

\section{Conclusion}

As already been explained, this article is extending the previous work in 2017 IEEE International Conference on Industrial Engineering and Engineering Management (IEEM) [1]. In this article, we added the concept of firm life cycle and data from interviews with experts. The novelty of this article is by added firm life cycle concept in PSS management. This concept is added because of the knowledge regarding industrial estate firms will follow a firm life cycle pattern [41]. As discussed earlier, that would create differences with the condition [28] and strategy needed [29]. Therefore, different PSS management would be promptly needed.

From the above discussion, it can be concluded that the concept of PSS can be applied to help Indonesian industrial estate firms to be sustainable across their life cycle. This is strengthened by data and interview results that many Indonesian industrial estate firms have started to think and provide services combined with products sales. Among firms, there are differences of services provided and business activities done. These findings are in line with the reference that state industrial estate firms need to shift to provide service for further development to be sustained [36].

Facing the firm life cycle, industrial estate firms can use the three types of PSS with the business activities. Industrial estate firms can do business activities that are suitable for their conditions regarding with firm life cycle. The type and business activities can be changed when the condition of the firm change along the firm life cycle. The suitable PSS management would lead to firms' sustainability in each life cycle. The conceptual framework suggests that the types of PSS implementations can assist industrial estate firms at each stage of the firm life cycle through creative innovation of the services provided to enable the industrial area to play its role well.

From the data, it is also found that the more the service composition is provided, the industrial estate firm will have more flexibility to innovate creatively. The more innovation would lead to more opportunity creation and the ability to choose the right business and service type. With this benefit, the industrial estate firms would get a competitive advantage, not to mention sustainability.

The implication of the findings is that industrial estate firms need to manage their PSS as an attempt to be sustained. They better plan the PSS in the beginning for they can get more stable and continuous profit. The planning for PSS from the beginning will also ease industrial estate firms to allocate the service facilities in the industrial estate and maintain good integration in the estate.

This article will help industrial estate firms to see opportunities for business activities that meet the conditions that can be applied at each stage of the firm life cycle based on the PSS concept. This concept also provides suggestions for industrial estate firms in determining strategies at each stage of the firm life cycle to be sustainable. For the government, this article will support the 


\section{Wirawan, et al. / Advances in Science, Technology and Engineering Systems Journal Vol. 3, No. 5, 128-139 (2018)}

government's efforts to develop appropriate policies in the development of the industry through the role of the industrial estate, which in turn improves the national economy and welfare. In the academic field, this article presents the incorporation of industrial estate concepts, corporate life cycles and PSS that are currently unexamined. This conceptual framework can generally be used for industrial estate firms because the basic theory used is general. However, since the empirical data in this article are only taken from industrial estate firms in Indonesia, there may be differences in government regulations, and conditions of competition, business, economy, industry conditions, etc for other countries that may require adjustment.

The implementations of PSS in this article are identified from the websites of industrial estates award winners and the interviews with industrial estate firms experts. For a better study, data from the websites need to be triangulated to get better descriptions. In addition, for further research, it is necessary to study more industrial estates to strengthen the results obtained. The study with non-award winners industrial estate firms also needs to be conducted to study to further test the concept. Moreover, the new and middle age industrial estate firms also need to be studied, to confirm the concept. Then our next research is to test the conceptual framework that has been built with interviews with several industrial estate firms with different conditions.

Further research about the comparison between private and public industrial areas as well as the comparison between industrial areas located in Java and those located outside Java should be employed. Research can also be extended by combining other concepts of operational strategies. Another research can also be conducted to study the firm life cycle pattern. Further study would also be needed to study the industrial estate firms with various time operated to better see the pattern of implementation of each type of PSS in industrial firms.

\section{Conflict of Interest}

The authors declare no conflict of interest

\section{Acknowledgment}

First author thanks the Education Fund Manager Institution (Lembaga Pengelola Dana Pendidikan/LPDP) in The Ministry of Finance, and The Ministry of Research, Technology and Higher Education, Republic of Indonesia for funding this research. Authors also thank Ms. Prameshwara Anggahegari for proofreading this manuscript.

\section{References}

[1] C. Wirawan, G. Yudoko, and Y. D. Lestari, 'Product-service system for Indonesian industrial estate firms : A conceptual framework', in Proceedings of 2017 IEEE IEEM, Singapore, 2017, 1812-1816.https://doi.org/ 10.1109/IEEM.2017.8290204

[2] P. Scott, 'Industrial Estates and British Industrial Development, 1897-1939', Bus. Hist., 43(2), 73-98, 2001.http://dx.doi.org/10.1080/713999223

[3] A. R. R. Ramos and F. P. Fonseca, 'A methodology to identify a network of industrial parks in the Ave Valley, Portugal', Eur. Plan. Stud., 20(10), 18441862, 2016.http://dx.doi.org/10.1080/09654313.2016.1202201

[4] World Bank Group, Getting to Green - A Sourcebook of Pollution Management Policy Tools for Growth and Competitiveness. www.worldbank.org, 2012.

[5] F. Fonseca, R. A. R. Ramos, and A. N. R. da Silva, 'An agent-based model to assess the attractiveness of industrial estates', Jasss, 18(4), 1-11,
2015.DOI: 10.18564 /jasss. 2893

[6] United Nations Industrial Development Organization, 'Economic Zones in the ASEAN: Industrial parks, special economic zones, eco-industrial parks, innovation districts as strategies for industrial competitiveness', August. 2015. DOI:10.1016/j.indmarman.2016.03.001

[7] B. R. Scott, Stages of corporate development. Boston: Harvard Business School Press, 1971.

[8] H. Mintzberg, 'Power and Organization Life Cycle', Acad. Manag. Rev., 9(2), 207-224, 1984

[9] O. K. Mont, 'Clarifying the concept of product-service system', J. Clean Prod., 10(3), 237-245, 2002. https://doi.org/10.1016/S09596526(01)00039-7

[10] T. S. Baines, H. Lightfoot, E. Steve, A. Neely, R. Greenough, J. Peppard, R. Roy, E. Shehab, A. Braganza, A. Tiwari, J. Alcock, J. Angus, M. Bastl, A. Cousens, P. Irving, M. Johnson, J. Kingston, H. Lockett, V. Martinez, P. Michele, D. Tranfield, I. Walton, and H. Wilson, 'State-of-the-art in product service-systems', in Proceedings IMechE, 221 Part B: J. Engineering Manufacture, 221, 1543-1552, 2007.DOI: 10.1243/09544054JEM858

[11] A. P. B. Barquet, M. G. de Oliveira, C. R. Amigo, V. P. Cunha, and H. Rozenfeld, 'Employing the business model concept to support the adoption of product-service systems (PSS)', Ind. Mark. Manag., 42, 693-704, 2013.http://dx.doi.org/10.1016/j.indmarman.2013.05.003

[12] CDMI Consulting Group, 'Studi potensi bisnis dan pelaku utama kawasan industri di Indonesia 2016-2020', Jakarta, 2015.

[13] Republic of Indonesia Industrial Ministry, Rencana Induk Pembangunan Industri Nasional 2015-2035 (National Industrial Master Plan 2015-2035). 2015.

[14] Republic of Indonesia., 'Undang-Undang Republik Indonesia Nomor 3 Tahun 2014 Tentang Perindustrian (Republic of Indonesia Law no. 3 the year of 2014)'.

[15] Republic of Indonesia. Industrial Ministry., 'Peraturan Pemerintah Republik Indonesia Nomor 142 Tahun 2015 Tentang Kawasan Industri (Republic of Indonesia Government Regulation No. 142 the year of 2015 about industrial estate)'.

[16] G. Yudoko, 'Strategy map for industrial estate firms: model building in the Indonesia Regulatory Context', Adv. Sci. Lett., 22(12), 4316-4320, 2016.https://doi.org/10.1166/asl.2016.8136

[17] G. Yudoko, 'The Indonesia Industrial Estate Firm Award's: Theory Building and Testing', Soc. Sci., 11(6), 7341-2345, 2016.

[18] J. Elkington, 'Enter the Triple Bottom Line', in The Triple Bottom Line: Does It All Add up? A. Henriques and J. Richardson, Eds. London: Earthscan, 2004, 1-16.

[19] E. Dewberry, M. Cook, A. Angus, A. Gottberg, and P. Longhurst, 'Critical Reflections on Designing Product Service Systems', Des. Journal, 6(4), 408-430, 2013.DOI: 10.1016/j.compind.2012.02.006

[20] S. Wiesner, M. Freitag, I. Westphal, K.-D. Thoben, and X. Boucher, 'Interactions between service and product lifecycle management', in Procedia CIRP, 2015, 221, 36-41.DOI: 10.1016/j.compind.2012.02.006

[21] S. Cavalieri and G. Pezzotta, 'Product-service systems engineering: State of the art and research challenges', Comput. Ind., 63, 278-288, 2012.DOI: 10.1016/j.compind.2012.02.006

[22] V. Zanetti, S. Cavalieri, and G. Pezzotta, 'Additive Manufacturing and PSS: a Solution Life-Cycle Perspective', IFAC-PapersOnLine, 49(12), 1573 1578, 2016.DOI: 10.1016/j.ifacol.2016.07.804

[23] S. Singhal and A. Kapur, 'Industrial estate planning and management in India - An integrated approach towards industrial ecology', J. Environ. Manage., 66, 19-29, 2016.DOI: 10.1006/jema.2002.0571

[24] V. Veleva, S. Todorova, P. Lowitt, N. Angus, and D. Neely, 'Understanding and addressing business needs and sustainability challenges: lessons from Devens eco-industrial park', J. Clean. Prod., 87, 375-384, 2015.http://dx.doi.org/10.1016/j.jclepro.2014.09.014

[25] C. K. Prahalad and V. Ramaswamy, 'Co-creating unique value with customers', Strateg. Leadersh., 32(3), 4-9, 2004.

[26] I. M. Jawahar and G. L. McLaughlin, 'Toward a descriptive stakeholder theory: An organizational life cycle approach', Acad. Manag. Rev., 26(3), 397-414, 2001.https://doi.org/10.5465/amr.2001.4845803

[27] D. C. Mueller, 'A Life Cycle Theory of the Firm', 20(3), 199-219, 2013.DOI $10.2307 / 2098055$

[28] C. R. Anderson and C. P. Zeithaml, 'Stage of product life cycle, business strategy, and business performance', Acad. Manag. J., 27, 5-24, 1984.https://doi.org/10.5465/255954

[29] S. H. Hanks, C. J. Watson, E. Jansen, and G. N. Chandler, 'Tightening the life-cycle construct: A taxonomic study of growth stage configurations in organizations', Entrep. Theory Pract., 18(2), 5-30, 1993.https://doi.org/10.1177/104225879401800201 
[30] A. Chandler, 'Strategy and structure'. Cambridge. MA, MIT Press, 1962.

[31] R. E. Quinn and K. Cameron, 'Organizational life cycles and shifting criteria of effectiveness: some preliminary evidence', Manage. Sci.,29(1), 33-51, 1993.https://doi.org/10.1287/mnsc.29.1.33

[32] M. Kuncoro and S. Wahyuni, 'FDI impacts on industrial agglomeration: the case of Java, Indonesia', J. Asia Bus. Stud., 3, 65-77, 2009.https://dx.doi.org/10.1108/03068290910921226

[33] T. Firman, 'Rural to urban land conversion in Indonesia during boom and bust periods', Land use policy, 17(1), 13-20, 2000.DOI: 10.1016/S02648377(99)00037-X

[34] M. J. Goedkoop, C. J. van Halen, H. R. te Riele, and P. J. Rommens, 'Product Service systems, Ecological and Economic Basics', PricewaterhouseCoopers N.V. / Pi!MC, Storm C.S., Pre consultants, 1999.

[35] A. Tukker, 'Eight types of product-service system: Eight ways to sustainability? Experiences from suspronet', Bus. Strateg. Environ., 13, 246-260, 2004.DOI: 10.1002/bse.414

[36] D. Mulyadi, Manajemen Perwilayahan Industri, First. Jakarta, Indonesia: Leuser Cita Pustaka, 2012.

[37] M. Lindahl, E. Sundin, and T. Sakao, 'Environmental and economic benefits of Integrated Product Service Offerings quantified with real business cases', J. Clean. Prod., 64, 288-296, 2014. DOI: 10.1016/j.jclepro.2013.07.047

[38] S. M. Lee, D. L. Olson, and S. Trimi, 'Co-innovation: Convergenomics, collaboration, and co-creation for organizational values', Manag. Decis., 50(5), 817-831, 2012. DOI: 10.1108/00251741211227528

[39] Y. Geum and Y. Park, 'Designing the sustainable product-service integration: A product-service blueprint approach', J. Clean. Prod., 19, 1601-1614, 2011.DOI: $10.1016 /$ j.jclepro.2011.05.017

[40] R. A. Swanson and T. J. Chermack, Theory Building in Applied Disciplines. San Francisco: Berret-Koehler Publishers, Inc., 2013.

[41] F. Belussi and S. R. Sedita, 'Life Cycle vs. Multiple Path Dependency in Industrial Districts', Eur. Plan. Stud., 17(4), 505-528, 2009.DOI: $10.1080 / 09654310802682065$

[42] 'Karawang International Industrial City'. [Online]. Available: www.kiic.com. [Accessed: 09-Jun-2017].

[43] 'Jababeka \& Co. Industrial'. [Online]. Available: www.jababeka.com. [Accessed: 09-Jun-2017].

[44] 'MM2100 Industrial Town'. [Online]. Available: www.mm2100.ac.id. [Accessed: 09-Jun-2017].

[45] 'Batamindo Investment Cakrawala'. [Online]. Available: www.batamindoindustrial.com. [Accessed: 09-Jun-2017].

[46] Nurhidayat, 'Kawasan Ekonomi Khusus ( KEK ) Sei Mangkei Menuju EcoIndustrial Park', National Seminar on Palm Oil Insight Panel Speech. Yogyakarta, 2018 